\section{Relative Susceptibility of Pecan Cultivars to Fungal Leaf Scorch and its Interaction with Irrigation}

\author{
B.W. Wood, C.C. Reilly, and W.L. Tedders \\ U.S. Department of Agriculture, Agricultural Research Service, Southeastern \\ Fruit and Tree Nut Research Laboratory, Byron, GA 31008
}

Additional index words. water stress, sugars, nitrogen, anthracnose, yield, alternate bearing, Carya illinoinensis

\begin{abstract}
Fungal leaf scorch, a potentially devastating disease in pecan [Carya illinoinensis (Wangenh.) K. Koch] orchards, was influenced substantially by irrigation and genotype. Three years of evaluating 76 pecan cultivars revealed that all cultivars exhibited scorch symptoms and that at least three classes of scorch susceptibility existed. Severity of symptoms was also much greater in nonirrigated than irrigated trees, and there were substantial differences in the concentrations of free nitrogenous compounds and free sugars in leaves between irrigated and nonirrigated trees.
\end{abstract}

Fungal leaf scorch is a major cause of premature defoliation of pecan trees throughout the southeastern United States. This defoliation typically occurs during dry periods in September, but symptoms may appear as early as July and August (Littrell and Worley, 1975) Affected leaflets wither, die, and abscise from the compound leaf. Because of the deleterious influence of defoliation on nut development and return bloom (Sparks and Brack, 1972; Worley, 1979a, 1979b; Worley, 1971), this problem can decimate orchard yields and trigger severe alternate bearing and associated yield and marketing problems (Wood, 1991).

Until recently, the etiology of fungal leaf scorch was unknown. Fungal involvement was demonstrated because applications of any one of several fungicides provided a measurable degree of protection (Littrell and Worley, 1973a, 1973b, 1973c, 1975). A Phomopsis sp. was identified as one causal agent in the disease, as well as Glomerella cingulata (Ston.) Spauld. and H. Schrenk (Reilly et al., 1994). Both fungi are pathogens of fruit and foliage and form a disease complex with symptoms appearing from August through harvest (Brenneman and Reilly, 1989; Rand, 1914; Reilly et al., 1994; Reilly and Reynolds, 1994).

There is evidence that the susceptibility of pecan cultivars to fungal leaf scorch may vary with the "stion", i.e., the genetic makeup of the compound trees typically used in orchards (Littrell and Worley, 1975; Rand, 1914). Subjective observations indicate that environmental stress factors influence leaf scorch, but there have been no reports of objectively derived data to confirm this hypothesis. Since scorch is potentially such a devastating phenomena and has not been adequately con-

Received for publication 23 May 1994. Accepted for publication 23 Sept. 1994. The cost of publishing this paper was defrayed in part by the payment of page charges. Under postal regulations, this paper therefore must be hereby marked advertisement solely to indicate this fact. trolled by pesticides, information concerning relative cultivar susceptibility and the role of stress factors, such as inadequate availability of water, is important with regard to providing a means of minimizing its occurrence and economic impact. This communication presents evidence of genetic variability in the susceptibility of pecan to scorch, identifies relative susceptibilities of 76 scion cultivars, and provides evidence for a major role for water in scorch development.

\section{Materials and Methods}

The relative sensitivity of scion cultivars to scorch and the role of soil moisture in scorch development was evaluated in two experiments. In both studies, the severity of fungal rating scale of 1 to 6 with the following symptom descriptors: 1 = none visible; $2=$ evident on $1 \%$ to $25 \%$ of shoots; $3=$ on $\approx 25 \%$ to $50 \%$ of shoots; $4=$ on $\approx 50 \%$ to $\approx 75 \%$ of shoots; $5=$ on $\approx 75 \%$ to $100 \%$ of shoots; and $6=$ at least $75 \%$ of the tree defoliated.

Evaluation of cultivar susceptibility. Seventy-six scion cultivars were evaluated for fungal leaf scorch from 1991 to 1993. Trees were established on Curtis rootstocks in 1984 and spaced on a $9 \times 9-\mathrm{m}$ spacing. Trees received fertilization according to Georgia Cooperative Extension Service recommendations as assessed by leaf analysis. Supplemental water was provided by drip irrigation where individual trees typically received from 121 to 363 liters/day during dry periods of the growing season. The design was a randomized block consisting of two blocks of two trees per cultivar (i.e., 304 trees). Blocks were based on soil differences. Scorch evaluations were made at the peak of the expression of scorch symptoms, which was the third week of September. Data analysis was by SAS-CATMOD followed by the Scott-Knott clustering procedure, using means derived from the categorical data, to separate general differences in leaf scorch was assessed categorically on a cultivar susceptibility levels (SAS Institute, 1988).

Evaluation of influence of irrigation on scorch. Study sites consisted of three orchards comprised of one of each of three cultivars ('Cheyenne', 'Desirable', and 'Wichita'). Trees were from 10 to 20 years old, depending on the orchard, and were growing on a $9 \times 9$ $\mathrm{m}$ square spacing. The orchards received good nutritional management, according to Extension Service recommendations. Trees within the three orchards were relatively uniform with respect to the degree of bearing, tree size, fertility, pesticides, etc., except for level of irrigation.

Irrigation treatments in the 'Wichita' orchard were arranged in a randomized complete-block design with six blocks consisting of four trees per block. All four trees per plot were rated for scorch symptoms. Plots were sprinkler-irrigated at 770 liters/day per tree, but the nonirrigated trees depended solely on moisture from natural rainfall. Irrigation treatments in the 'Cheyenne' and 'Desirable' orchards were arranged, due to constraints in the layout of the system, as a single large block of drip-irrigated trees receiving 242 liters/tree per day (from late July until October) and the remainder receiving no supplemental irrigation. The study block in the 'Cheyenne' orchard consisted of eight rows of eight trees per irrigation treatment, whereas the study block in the 'Desirable' orchard consisted of a block of 20 rows of 25 trees per irrigation treatment. Scorch ratings in the latter two orchards were therefore evaluated by $t$ test $(\alpha \leq 0.05)$ and standard errors, whereas the 'Wichita Orchard' was evaluated by SAS's analysis of variance procedure (SAS Institute, 1988). Each orchard consisted of trees historically managed in a relatively uniform manner. Relative differences in water availability varied during the entire growing season, resulting in obvious differences in leaf scorch by mid-September. Rainfall for these orchards during the study period is characterized in Fig. 1.

Differences in free sugar and nitrogenous substances in green foliage from the two irrigation treatments in each of the three orchards were assessed colorimetrically according to standard procedures (Wood, 1988). Leaflet disks were taken from apparently healthy leaflets, extracted with alcohol, and assayed. Samples consisted of 20 disks taken randomly per tree for each of the study trees.

\section{Results}

Evaluation of cultivar susceptibility. Scorched leaflets had light brown necrotic lesions, usually beginning at the leaf margin and progressing toward the midrib. This necrotic area was delineated from the healthy leaf tissue with a conspicuous dark brown line. On some leaves, the necrosis began at the leaf tip and moved toward the petiole on both sides of the midrib. The infected area eventually developed throughout the entire leaflet and in many instances resulted in abscission. The symptoms were consistent with those previously reported (Littrell and Worley, 1975). 

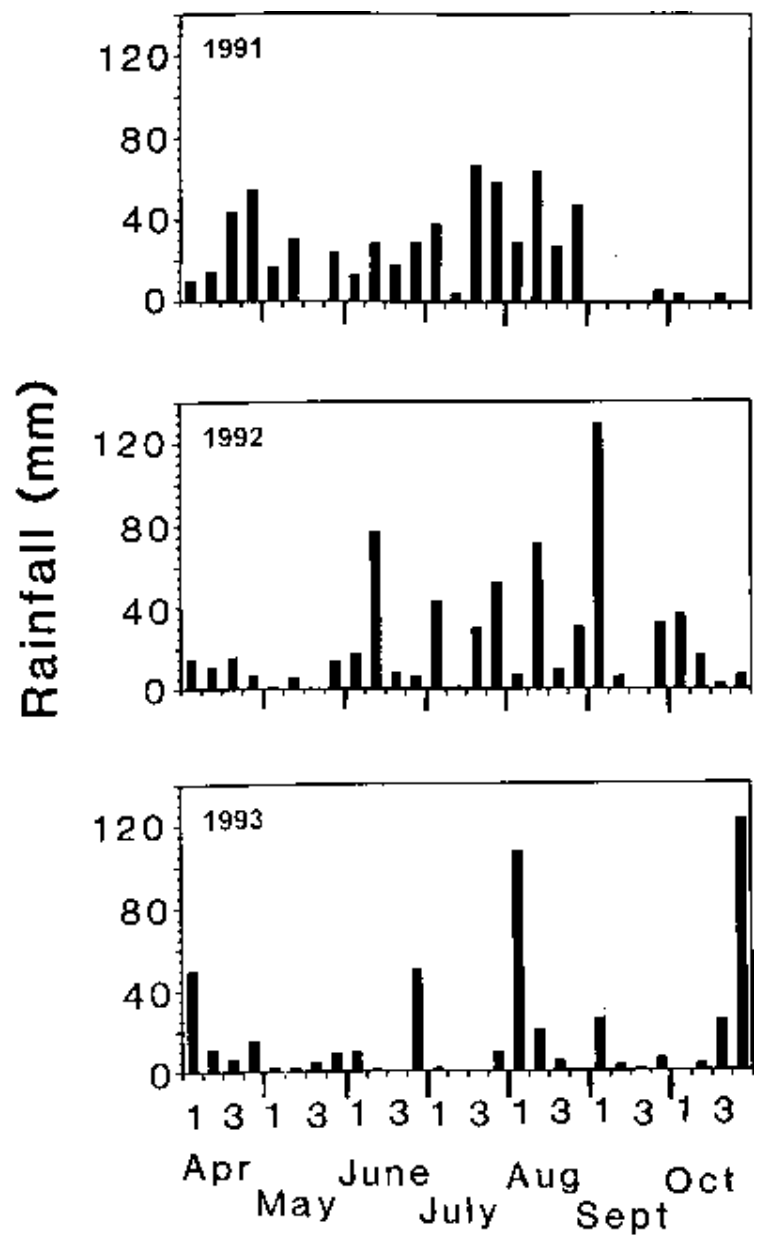

Week of month

Fig. 1. Rainfall patterns by weekly intervals from 1991 to 1993 at orchards exhibiting fungal leaf scorch symptoms. The fourth interval includes days from the $22 \mathrm{nd}$ day of the month to the last day of the month.

Clustering analysis of ratings taken over the three years for 76 scion cultivars indicated clear differences in the incidence of fungal leaf scorch depending on genotype (Table 1). Analysis of derived means by Scott-Knot clustering technique separated the population into three distinct groupings. No cultivar was free of fungal leaf scorch symptoms, although $26 \%$ clearly exhibited less severe symptoms than did the others $(\alpha \leq 0.001)$, and this level was relatively low (symptoms on $1 \%$ to $25 \%$ of shoots on the tree). A second group exhibiting more severe scorch was separated $(\alpha \leq 0.01)$ from a third group exhibiting yet a greater level of scorch. This second, or moderate, group comprised $28 \%$ of the sample population. The high scorch group separated at $\alpha \leq$ 0.18 to potentially describe a fourth group consisting of $16 \%$ of the sample population exhibiting especially severe leaf scorch and trees that were largely defoliated. Cultivars exhibiting the least fungal leaf scorch were 'Pabst', 'Woodard', and 'Woodruff', whereas severity was greatest in 'Hirschi', 'Norton', 'Riverside', and 'Starking Hardy Giant'.

There was essentially no scorch observed in 1992 regardless of genotype. While the 1992 growing season was much wetter than the 1991 or 1993 growing season (Fig. 1), trees also exhibited a light nut set, whereas nut set was heavy in 1991 and 1993.

Evaluation of influence of irrigation on scorch. Fungal leaf scorch symptoms were expressed on irrigated and nonirrigated trees. The severity of fungal leaf scorch symptoms in orchards of all three cultivars was always greater on nonirrigated than irrigated trees (Table 2). Leaves of nonirrigated trees also contained higher concentrations of free amino acid equivalents and free sugar equivalents than those of irrigated trees.

\section{Discussion}

This evaluation of many commonly planted pecan cultivars revealed segregation into three distinct susceptibility classifications, with all 76 cultivars exhibiting fungal leaf scorch during September of the two crop seasons when bearing was heaviest $(1991,1993)$. Few, if any, symptoms were evident on these cultivars during the crop year of low nut production (1992), which also had a relatively wet September. Thus, the possible influence of "fruiting stress" on scorch was confounded with seasonal precipitation differences or other environmental factors (Fig. 1). This pattern could, however, be interpreted as 1) circumstantial evidence that fruit load may greatly influence a tree's expression of scorch symptoms and 2) that there may be substantial interactive effects between fruit load and water availability with respect to degree of scorch-type damage.

The relative scorch ratings of these 76 cultivars should not necessarily be interpreted as relative resistance/susceptibility, since stress factors, such as water availability (and probably fruit load, shading, nutrient elements), as indicated by the differential irrigation treatments of this study (Table 2), interact with genotype to influence substantially susceptibility to fungal leaf scorch. While water availability was essentially uniform throughout this cultivar trial, crop load per tree (or leaf area per weight of kernel) varied greatly; hence, some cultivars exhibiting low levels of scorch might well be expected to exhibit much higher levels of scorch under different stress conditions. For example, 'Success' is one cultivar that exhibited low scorch rating in this study but is recognized by growers as commonly exhibiting severe scorch and premature defoliation in commercial orchards. Similarly, relative susceptibility of 24 pecan cultivars, as determined by evaluation for one season (Littrell and Worley, 1975), deviated markedly from the data of our study.

The cultivars that exhibited high scorch ratings (i.e., 4 to 6 ) are therefore likely to be especially susceptible to scorch-related defoliation, particularly under water stress conditions and possibly under considerable fruiting stress. These data indicate that all pecan cultivars likely are subject to premature defoliation due to fungal leaf scorch if exposed to enough water stress. This effect also may result from other stress, such as fruit load.

The role of the elevated levels of free nitrogenous compounds and free sugars in stressed (i.e., nonirrigated) foliage is unknown, while such conditions may possibly contribute to the scorch of the foliage susceptibility. Our study does not permit us to conclude whether these biochemical changes occur as a result of scorch or preceded scorch symptoms and were, therefore, induced directly via water stress or indirectly due to other factors. Littrell and Worley (1975) reported a relatively weak ( $r=$ -0.33 ) negative correlation between total leaflet $\mathrm{N}$ content and fungal leaf scorch; the higher levels of free $\mathrm{N}$ in leaves of trees exhibiting severe symptoms in our study would tend to support this proposed inverse relationship with total N. These data therefore raise important questions as to whether high levels of free $\mathrm{N}$ and free sugars in foliage of trees with higher scorch ratings contribute to growth of microorganisms that either cause or contribute to fungal leaf scorch.

Our data indicate that, while pecan cultivars appear to respond differentially to fungal leaf scorch, all cultivars are likely to exhibit symptoms under conditions of water stress, and possibly other stress factors, such as heavy fruit loads. Also, selection from among the currently available cultivar pool may not be a viable means of escaping scorch and its associated problems, although the degree of scorch exhibited by some cultivars may be substan- 
Table 1. Scott-Knott cluster analysis of relative levels of fungal leaf scorch exhibited by 76 pecan cultivars during the 1991-93 growing seasons. ${ }^{2}$

\begin{tabular}{|c|c|c|c|c|c|}
\hline \multicolumn{6}{|c|}{ Susceptibility } \\
\hline \multicolumn{2}{|c|}{ Lowest } & \multicolumn{2}{|c|}{ Moderate } & \multicolumn{2}{|c|}{ Highest } \\
\hline Cultivar & Rating $^{y}$ & Cultivar & Rating $^{\mathrm{y}}$ & Cultivar & Rating \\
\hline Pabst & 2 & Comanche & 3.2 & Pawnee & 4.2 \\
\hline Woodard & 2 & Podsednik & 3.3 & Peruque & 4.2 \\
\hline Woodruff & 2 & Caddo & 3.5 & Shoshoni & 4.2 \\
\hline Farley & 2.2 & Melrose & 3.5 & Cowley & 4.5 \\
\hline Maramec & 2.2 & Russell & 3.5 & Dependable & 4.5 \\
\hline Curtis & 2.5 & Kernodle & 3.7 & Forkert & 4.5 \\
\hline Gracross & 2.5 & Mohawk & 3.7 & Western & \\
\hline Success & 2.5 & Apache & 3.8 & Schley & 4.5 \\
\hline Gratex & 2.7 & Graking & 3.8 & Frotscher & 4.7 \\
\hline Moneymaker & 2.7 & Harris & & Giles & 4.8 \\
\hline Odom & 2.7 & Super & 3.8 & Posey & 4.8 \\
\hline Sioux & 2.7 & Mahan & 3.8 & Stuart & 4.8 \\
\hline Waukeenah & 2.7 & Alley & 4 & Teche & 4.8 \\
\hline Brooks & 3 & Barton & 4 & Centennial & 5 \\
\hline Jackson & 3 & Candy & 4 & Choctaw & 5 \\
\hline Kiowa & 3 & Cape Fear & 4 & Colby & 5 \\
\hline Moreland & 3 & Cherokee & 4 & Dooley & 5 \\
\hline Owen & 3 & Ideal & 4 & Evers & 5 \\
\hline Shawnee & 3 & Nelson & 4 & Gloria & \\
\hline \multirow{21}{*}{ Sumner } & 3 & Pensacola & & Grande & 5 \\
\hline & & Clu. & 4 & Grabohls & 5 \\
\hline & & San Saba & 4 & Green & \\
\hline & & Van Deman & 4 & River & 5 \\
\hline & & & & Johnson & 5 \\
\hline & & & & Love & 5 \\
\hline & & & & Major & 5 \\
\hline & & & & Chickasaw & 5.3 \\
\hline & & & & Delmas & 5.5 \\
\hline & & & & Mobile & 5.5 \\
\hline & & & & San Saba & \\
\hline & & & & Imp. & 5.5 \\
\hline & & & & Tejas & 5.5 \\
\hline & & & & Wichita & 5.5 \\
\hline & & & & Elliott & 5.7 \\
\hline & & & & Squirrel's & \\
\hline & & & & Delight & 5.7 \\
\hline & & & & Hirschi & 6 \\
\hline & & & & Norton & 6 \\
\hline & & & & Riverside & 6 \\
\hline & & & & Starking & 6 \\
\hline
\end{tabular}

${ }^{2}$ Ratings taken in Sept. 1991, 1992, and 1993. No symptoms were observed in 1992. The 1991 and 1993 seasons were "on" years for bearing, whereas 1992 was an "off" year. Scott-Knott clustering separation at $\alpha \leq 0.0001$ splits the group between 'Van Deman' and 'Pawnee'; separation at $\alpha \leq 0.01$ split the group between 'Sumner' and 'Commanche'; further separation is at $\alpha \leq 0.18$ and would split between 'Major' and 'Chickasaw'.

'Rating was on a scale of 1 to 6 , where $1=$ none visible; $2=$ evident on $1 \%$ to $\approx 25 \%$ of shoots; $3=$ on $\approx 25 \%$ to $50 \%$ of shoots; $4=$ on $\approx 50 \%$ to $75 \%$ of shoots; $5=$ on $\approx 75 \%$ to $100 \%$ of shoots; and $6=$ at least $75 \%$ of tree defoliated.

Table 2. Influence of irrigation in 1993 on fungal leaf scorch, amino acid equivalents, and glucose equivalents associated with the foliage of three pecan cultivars.

\begin{tabular}{lccr}
\hline \hline & & Cultivar & \\
\cline { 2 - 4 } Variable & Cheyenne & Desirable & Wichita \\
\hline Scorch rating & \\
$\quad$ Irrigated & 2.0 & 2.8 & 2.4 \\
$\quad$ Nonirrigated & 4.7 & 4.1 & 3.5 \\
$\quad$ SE $P$ & 0.4 & 0.5 & $\alpha \leq 0.001$ \\
Free amino acid equivalents $\left(\mathrm{mmol} \cdot \mathrm{cm}^{-2}\right)^{\mathrm{y}}$ & & & \\
$\quad$ Irrigated & 22.9 & 11.0 & 13.1 \\
$\quad$ Nonirrigated & 26.1 & 16.8 & 12.0 \\
SE or $P$ & 2.9 & 2.3 & $\alpha \leq 0.05$ \\
Free sugar equivalents $\left(\mu \mathrm{mol} \cdot \mathrm{cm}^{-2}\right)^{\mathrm{x}}$ & & & \\
$\quad$ Irrigated & 97 & 82 & 90 \\
$\quad$ Nonirrigated & 164 & 112 & 121 \\
SE or $P$ & 14 & 11 & $\alpha \leq 0.001$ \\
\hline
\end{tabular}

${ }^{2}$ Rating was on a scale of 1 to 6 , where $1=$ none visible; $2=$ evident on $1 \%$ to $\approx 25 \%$ of shoots; $3=$ on $\approx 25 \%$ to $50 \%$ of shoots; $4=$ on $\approx 50 \%$ to $75 \%$ of shoots; $5=$ on $\approx 75 \%$ to $100 \%$ of shoots; and $6=$ at least $75 \%$ of tree defoliated.

yBased on glycine.

${ }^{\mathrm{x} B a s e d}$ on glucose. tially less than that of others. Our data also indicate that scorch and premature defoliation can be reduced by keeping trees well-watered. A key point meriting research is whether fungal leaf scorch can occur on nonstressed trees and whether it can be controlled on stressed trees with appropriate and timely fungicide applications.

\section{Literature Cited}

Brenneman, T.B. and C.C. Reilly. 1989. Recent occurrence of pecan anthracnose caused by Glomerella cingulata. Plant Dis. 73:775.

Littrell, R.H. and R.E. Worley. 1973a. Mycoflora associated with leaf scorch of pecan. Phytopathology 62:805.

Littrell, R.H. and R.E. Worley. 1973b. Fungicide effects on internal mycoflora of pecan leaflets and severity of leaf scorch. Phytopathology 63:445.

Littrell, R.H. and R.E. Worley. 1973c. Foliar fungicides, leaf inhabiting fungi and development of leaf scorch. Proc. Southeastern Pecan Growers Assn. 66:73-78

Littrell, R.H. and R.E. Worley. 1975. Relative susceptibility of pecan cultivars to fungal leaf scorch and relationship to mineral composition of foliage. Phytopathology 65:717-718.

Rand, F.V. 1914. Some diseases of pecans. J. Agr. Res. 1(4):303-344.

Reilly, C.C., M.W. Hotchkiss, and K.L. Reynolds. 1994. A species of Phomopsis causing leaf and shuck necrosis and twig die-back in pecan. Plant Dis. (In press).

Reilly, C.C. and K.L. Reynolds. 1994. Fungi involved in fungal leaf scorch and shuck disease complex of pecan. Proc. Southeastern Pecan Growers Assn. 87:129-133.

SAS Institute. 1988. SAS/STAT user's guide, release 6.03 ed. SAS Inst., Cary, N.C.

Sparks, D. and C.E. Brack. 1972. Return bloom and fruit set of pecan from leaf and fruit removal. HortScience 7:131-132.

Wood, B.W. 1988. Fruiting affects photosynthesis and senescence of pecan leaves. J. Amer. Soc. Hort. Sci. 113:432-436.

Wood, B.W. 1991. Alternate bearing of pecan, p. 180-190. In: B.W. Wood and J.A. Payne (eds.). Pecan husbandry: Challenges and opportunities. Proc. First Natl.Pecan Wkshp. ARS-96:180190.

Worley, R.E. 1971. Effect of defoliation date on yield, quality, nutlet set, and foliage regrowth for pecan. HortScience 6:446-447.

Worley, R.E. 1979a. Pecan yield, quality, nutlet set, and spring growth as a response to time of fall defoliation. J. Amer. Soc. Hort. Sci. 104:192194.

Worley, R.E. 1979b. Fall defoliation date and seasonal carbohydrate concentration of pecan wood tissue. J. Amer. Soc. Hort. Sci. 104:195-199. 